\title{
Articles
}

\section{La(III) Selective Membrane Sensor Based on a New N-N Schiff's Base}

\author{
Mohammad Reza Ganjali, ' Parisa Matloobi, Maryam Ghorbani, \\ Parviz Norouzi, and Masoud Salavati-Niasari ${ }^{\dagger}$ \\ Department of Chemistry; Tehran Lniversity, Tehran, Iran. E-mail: Ganjaliakhavam.utacir \\ -Department of Chemistry, Kashan Liniversity, Kashan, Iran \\ Received November 27, 2003
}

\begin{abstract}
Bis(2-methỵlbenzaldehyde)butane-2.3-dihydrazone(TDSB) was used as new N-N Schiff's base which plays the role of an excellent ion carrier in the constniction of a $\mathrm{La}$ (III) membrane sensor. The best performance was obtained with a membrane containing. $30 \%$ polý(vinỵl chloride). $60 \%$ benzyl acetate. $6 \%$ TDSB and $4 \%$ sodium tetraphenyl borate. This sensor reveals a very good selectivity towards La(III) ions over a wide variety of cations. including alkali. alkaline earth transition and heavy metal ions. The proposed electrode exhibits a Nernstian behavior (with slope of $19.8 \mathrm{mV}$ per decade) over a wide concentration range $\left(1.0 \times 10^{-5}-1.0 \times 10^{-1}\right.$ $\mathrm{M})$. The detection limit of the sensor is $7.0 \times 10^{-6} \mathrm{M}$. It has a very short response time, in the whole concentration range $(\sim 5 \mathrm{~s})$, and can be used for at least twelve weeks in the $\mathrm{pH}$ range of 3.0-9.4. The proposed sensor was successfully applied as an indicator electrode for the potentiometric titration of a La(III) solution. with EDTA. It was also successfilly applied in the determination of fluoride ions in three mouth wash preparations
\end{abstract}

Key Words : La(III) sensor. Potentiometry, PVC. N-N Schiff's base

\section{Introduction}

Lanthanum oxide is widely used in the preparation of optical glasses. glass fibers for optical purposes. gasolinecracking catalysts. polishing compounds and carbon arcs. and in the iron and steel industries to remove sulfur, carbon. and other electronegative elements from iron and steel. Solvent polymeric membrane based ISEs, together with the incorporation of new ion carriers. have shown to be a very useful tool for clinical, envirommental. and chemical analyses as well as for process monitoring. In the area of membrane based ISEs, emphasis has been focused on the development of new ion-carriers. Fabrication of a new, ionspecific ISEs with high selectivity and sensitivity. wide linear concentration range, long lifetime and good reproducibility. is always in need. There have been many studies about ion-selective electrodes (ISEs) for different metal ions. 'Among these metal ions. little attention has been paid to the development of $\mathrm{La}$ (III) membrane sensors. -5

In recent years. we have reported a number of new PVCbased sensor for selective and sensitive monitoring of lanthanide ions such as Ce(III), La(III). Snt(III). Gd(III). and $\mathrm{Yb}(\mathrm{III}){ }^{6-1]}$ In this work we introduce a highly selective La(III) sensor by incorporating Bis(2-methy lbenzaldehỵde)butane-2,3-dihydrazone in a PVC-based membrane

\section{Experimental Section}

Reagents. Reagent grade acetophenone (AP). benzyl acetate (BA), dibuțl phthalate (DBP), o-nitrophenyloctỵl ether (NPOE), sodium tetraphenyl borate (TPB). tetrahydrofuran (THF) and high relative molecular weight PVC were purchased from Merck Chemical Company and used as received. Reagent grade chloride salts of all cations used (all from Merck). were of the highest purity available and used without any further purification except for vacuum drying. Doubly distilled deionized water was used throughout.

Synthesis of TDSB. TDSB was synthesized in two steps.

Step 1. The synthesis of 2.3-butanedilydrazone. 2.3butanedilydrazone was prepared by the Bush and Bailar method. $^{12}$ To a boiling solution of $11.63 \mathrm{~g}$ of aqueous hydrazine $(0.24 \mathrm{~mol})$ in $100 \mathrm{~mL}$ of methanol. was added 75 $\mathrm{mL}$ of biacetyl $(0.12 \mathrm{~mol}, 10.33 \mathrm{~g})$ over a period of $2 \mathrm{lurs}$. Refluxing was continued for an additional $1 \mathrm{~h}$. Two hundred milliliters of water was then added and the methanol was removed by distillation when the resulting aqueous solution was cooled in an ice-bath, with crystal formed. The crystals were filtered, washed with a little water, recrystallized from $100 \mathrm{~mL}$ of hot methanol and dried in vacuum.

Step 2. The synthesis of TDSB. TDSB (Figure 1) was prepared by the reaction of the 2-methylebenzaldehyde with diamine. This can be typified by the following preparation. To an ethanol solution $(100 \mathrm{~mL})$ of 2.3-butanedilydrazone ( $1.14 \mathrm{~g}, 0.1$ mole) was added 2-methylebenzaldehyde $(2.40$ g. 0.02 mole). This mixture was refluxed in a round bottom flask, fitted with a Dean Stark trap, to remove the water produced during the reaction, and concentrated to yield a yellow solid. The product was collected by filtration, 


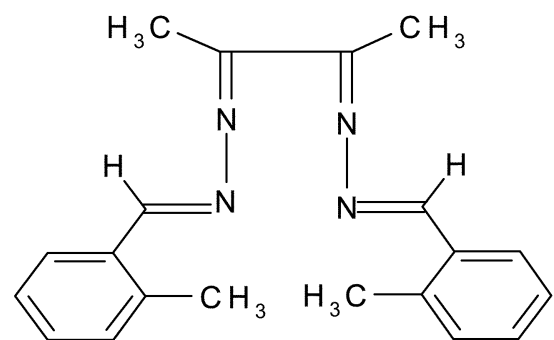

Figure I. Structure of TDSB.

washed witl a little water, recrystallized from $100 \mathrm{~mL}$, of hot ethanol and dried in vacuum (yield $-87 \%$ ). $\mathrm{mp}=126-127$ ${ }^{\circ} \mathrm{C},{ }^{1} \mathrm{H}-\mathrm{NMR}(200 \mathrm{MHz}, \mathrm{CDCl}), \delta 2.42\left(6 \mathrm{H}, \mathrm{s}, \mathrm{CH}_{3}\right), 2.62$ $\left(6 \mathrm{H}, \mathrm{s}, \mathrm{CH}_{3}\right), 7.45-7.60(8 \mathrm{H}, \mathrm{m}$, phenyl), $8.42(2 \mathrm{H}, \mathrm{s}$. $\mathrm{CH}=\mathrm{N}) ;{ }^{13} \mathrm{C}$ NMR data; $\delta 12.70$ and $19.95\left(2 \mathrm{CH}_{3}\right), 128.77$. $128.96,130.23$ and $131.49(4 \mathrm{CH}), 135.82,139.33(2 \mathrm{C})$. $159.75(\mathrm{CH}), 164.31$ (C). Anal. Caled for $\mathrm{CxHyNz}$ : , 75.44; H, 6.96; N, 17.59. Found: C, 75.23; H, 6.86; N. $17.64 \%$, IR $\left(\mathrm{KBr}, \mathrm{cm}^{-1}\right): 1608\left(v_{\mathrm{C}} \mathrm{v}\right) ; 1550\left(v_{\mathrm{C}}\right)$.

Electrode Preparation. Membrane solutions were prepared by thoroughly dissolving $6.0 \mathrm{mg}$ of 'JDSB, $30 \mathrm{mg}$ of powdered PVC, $60 \mathrm{mg}$ of BA and $4.0 \mathrm{mg}$ of ${ }^{\prime} \mathrm{PB}$ in $3 \mathrm{~mL}$ of fresh $\mathrm{IHF}$. The resulting clear mixture was evaporated slowly until an oily concentrated mixture was obtained. A l'yrex tube (3-5 mm o.d. on top) was dipped into the mixture for about $5 \mathrm{~s}$, so that a nontransparent membrane of about $0.3 \mathrm{~mm}$ thickness was formed. ${ }^{13.11}$ The tube was pulled out from the mixture and kept at room temperature for 12 hrs. The tube was then filled with an internal solution $\left(1.0 \times 10^{-3}\right.$ $\mathrm{M}$ l.aCly). The electrode was finally conditioned for $24 \mathrm{~h}$ by soaking in a $1.0 \times 10^{-2} \mathrm{M}$ lanthanum chloride solution. A silver/silver chloride electrode was used as the internal reference electrode.

The $\mathrm{pH}$ of all solutions was adjusted at 4.0 , using a buffer of acetic acid/lithium acetate.

EMF Measurements. The EMF measurements with the polymeric membrane were carried out with the following cell assemblies:

$\mathrm{Ag}-\mathrm{AgCl}$ internal solution. $1.0 \times 10^{-3} \mathrm{M} \mathrm{LaCl}_{3} \quad \mathrm{PVC}$ membrane / test solution $\mathrm{Hg}-\mathrm{Hg}_{2} \mathrm{Cl}_{2} \mid \mathrm{KCl}$ (satd)

The activities were calculated according to the DebyeHückel procedure. ${ }^{15}$

\section{Results and Discussion}

The existence of four donating nitrogen atoms in TDSB. was expected to increase both the stability and selectivity of its complexes with transition and heavy metal ions. ${ }^{6.11 .12 .16}$ Ihus, in order to check the suitability of TDSB as an ion carrier for different metal ions, it was used to prepare a number of PVC membrane ion-selective electrodes for a wide variety of cations, including alkali, alkaline earth and transition metal ions, The potential responses of the most sensitive ion-selective electrodes based on [DSB are given in Figure $2 a$ and $2 b$. As can be seen, except for the La(III) ion-selective electrode, in the case of all other cations tested.
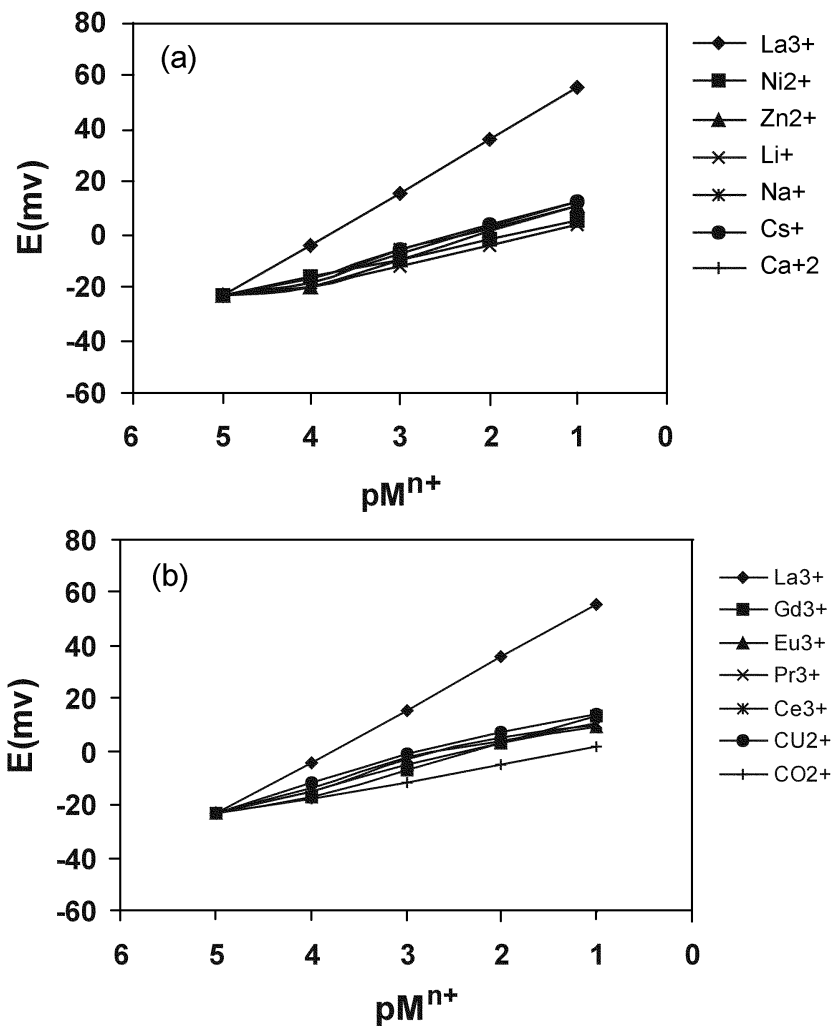

Figure 2. Potential responses of diflerent ionseleclive electrodes based on TDSB.

the slopes of the corresponding potential $\mathrm{pM}^{\mathrm{n}+}$ plots, is much lower than the expected Nernstian slopes of 59,29.5 and 20 $\mathrm{mV}$ per decade for the univalent, bivalent and trivalent cations, respectively. However, $\mathrm{La}$ (III) with the most sensitive response among all cations tested seems to be suitably determined with the membrane electrode based on IDSB. This is likely due to the high selectivity of the ion carrier towards La(III) ions, over other metal ions as well as the rapid exchange kinetics of the resulting $\mathrm{La}(\mathrm{Ill})$ - TDSB complex.

It is well understood that the sensitivity, linear dynamic range, and selectivity of the ISEs depend on, not only the nature of the carrier used, but also significantly on the

Table 1. Optimization of the membrane ingredients

\begin{tabular}{|c|c|c|c|c|c|}
\hline \multirow{2}{*}{$\begin{array}{l}\text { Number of } \\
\text { membranc }\end{array}$} & \multicolumn{4}{|c|}{ Composition (wt \%) } & \multirow{2}{*}{$\begin{array}{c}\text { Slope } \\
\text { (mV per decade) }\end{array}$} \\
\hline & PVC & Plasticizer & TDSB & $\mathrm{NaTPB}$ & \\
\hline 1 & 30 & BA. 65 & 5 & - & $8.4-0.1$ \\
\hline 2 & 30 & BA. 64 & 6 & - & $10.7=0.2$ \\
\hline 3 & 30 & BA. 63 & 7 & - & $8.8=0.1$ \\
\hline 4 & 30 & BA. 62 & 6 & 2 & $13.2=0.2$ \\
\hline 5 & 30 & BA. 61 & 6 & 3 & $17.7=0.3$ \\
\hline 6 & 30 & BA. 60 & 6 & 4 & $19.8=0.3$ \\
\hline 7 & 30 & AP. 60 & 6 & 4 & $18.8=0.5$ \\
\hline 8 & 30 & DBP. 60 & 6 & 4 & $17.7=0.2$ \\
\hline 9 & 30 & NPOE. 60 & 6 & 4 & $19.6=0.3$ \\
\hline 10 & 30 & BA. 66 & - & 4 & $3.7=0.1$ \\
\hline
\end{tabular}


membrane composition and the properties of the additives employed. ${ }^{17.18 .19 .20}$ Thus, the influence of the membrane composition, nature, and amount of the plasticizer, and lipophilic additives, on the potential response of the membranes were investigated and the results are given in Table 1 . As it can be seen, in the composition 6, the membrane incorporating $60 \% \mathrm{BA}$ and $30 \% \mathrm{PVC}$, in the presence of $6 \%$ TDSB and $4 \%$ [] sensitivity, with a Nernstian slope of $19.8 \mathrm{mV}$ per decade of $\mathrm{La}(\mathrm{l}] \mathrm{l})$ concentration.

The potentiometric response of the membranes was greatly improved in the presence of a lipophilic cationic additive (from slope of 10.7 to $19.8 \mathrm{mV}$ per decade for the membrane Nos. 2 and 6, respectively). It is well known that not only do the lipophilic salts reduce the membrane resistance, but they also enhance the response behavior and selectivity, and reduce interference from sample anion. ${ }^{21}$

The effect of the concentration of the internal solution on the potential response of the sensor was investigated. The lanthanum chloride concentration was changed from $1.0 \times$ $10^{-1}$ to $1.0 \times 10^{-2} \mathrm{M}$ and the corresponding $\Gamma \mathrm{MF}$ versus $\mathrm{pLa}^{3-}$ plots were obtained. It was found that the concentration of the internal solution has a negligible effect on the potential response of the electrode, except for an expected shift in the intercept of the resulting plots. A $1.0 \times 10^{-3} \mathrm{M}$ concentration of the filling solution was used for further studies.

The plot of EMF is. pLa ${ }^{3+}$ obtained under optimal membrane ingredients for the sensor ( $\mathrm{Fig.} \mathrm{3)}$, indicate that it has a Nernestian behavior over wide concentration ranges of $\mathrm{La}(J I I)$ ion. The slope and linear range of the resulting calibration graph were $19.8 \mathrm{mV}$ per decade and $1.0 \times 10^{-5}$ $1.0 \times 10^{-1} \mathrm{M}$, respectively. The limit of detection (1.OD), defined as the concentration of $\mathrm{La}(\mathrm{III})$ ion, obtained when the linear regions of the calibration graph extrapolated to the base line potential, is $7.0 \times 10^{-6} \mathrm{M}$.

The optimum equilibration time for the membrane sensor in the presence of $1.0 \times 10^{-3} \mathrm{M}$ lanthanum chloride was investigated and found to be $24 \mathrm{~h}$, after which the electrode

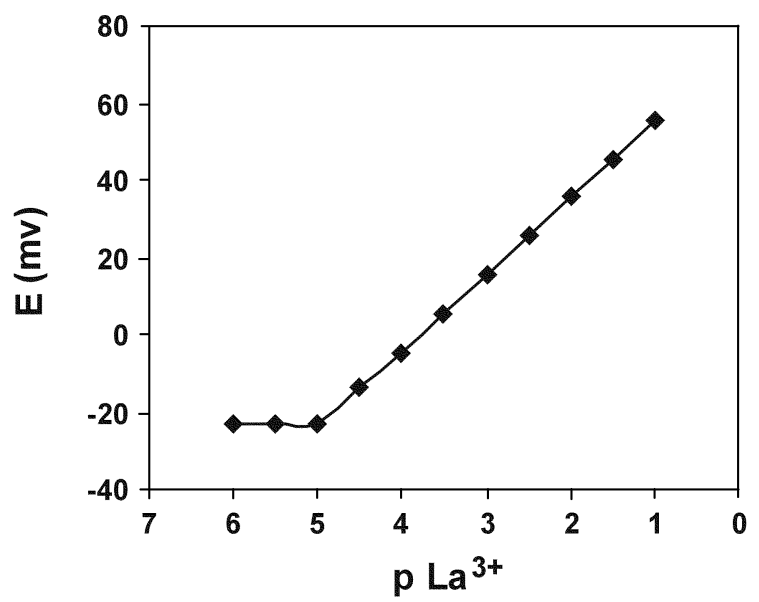

Figure 3. Calibration curves of lanthanum(III) electrode based on ILSB.

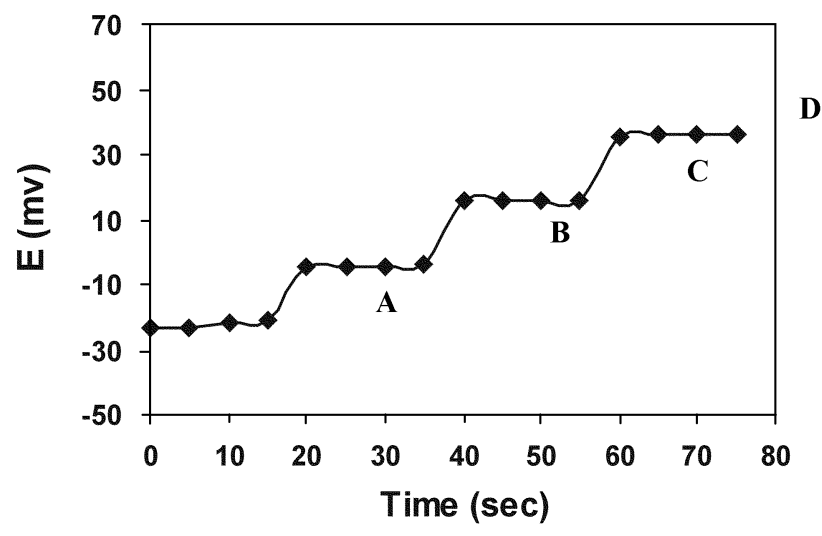

Figure 4. Dynamic response time of the lanthanum alectrode for step changes in the concentration of $\mathrm{L} . \mathrm{a}^{3}:$ (A) $1.0 \times 10^{-5} \mathrm{M}$, (B) 1.0 $\times 10^{-4} \mathrm{M}$. (C) $1.0 \times 10^{-5} \mathrm{M}$. (I) $1.0 \times 10^{-2} \mathrm{M}$.

generated stable potentials in contact with $\mathrm{la}(\mathrm{III})$ ion solutions. The standard deviation of 10 replicate potential measurements for proposed electrode was at the $\operatorname{most}=0.3$ $\mathrm{nV}$. The proposed electrode was very stable and could be used for at least 2 months without observing any change in its response characteristics.

For analytical purposes, response time is one of the most important factors that are taken into account. In this work. the practical response time was recorded by immediate and successive changing of $\mathrm{La}(\mathrm{I}] \mathrm{I})$ concentration from $1.0 \times 10^{-5}$ to $10 \times 10^{-1} \mathrm{M}$ and the results are shown in Figure 4. As it can be seen, in the whole concentration range, the electrode reaches to its equilibrium response in a very short time $(5 \mathrm{~s})$.

The $\mathrm{pH}$ dependence of the membrane sensor was tested over a $\mathrm{pH}$ range of $1.0-12.0$ in a $1.0 \times 10^{-3} \mathrm{M} \mathrm{la(11)}$ solution, and the results are illustrated in Figure 5 . As it can be seen, the potential remains fairly constant in a $\mathrm{pH}$ range of 3.0-9.4. Beyond this range, a gradual change in the potential was detected. The observed potential drift at the higher $\mathrm{pH}$ values could be due to the formation of some hydroxy complexes of $\mathrm{La}(\mathrm{IIJ})$ in the solution. At lower $\mathrm{pH}$ values, the potentials increased, indicating that the membrane sensor responds to proton ions, too.

The potentiometric selectivity coefficients, which reflected the relative response of the membrane sensor towards the

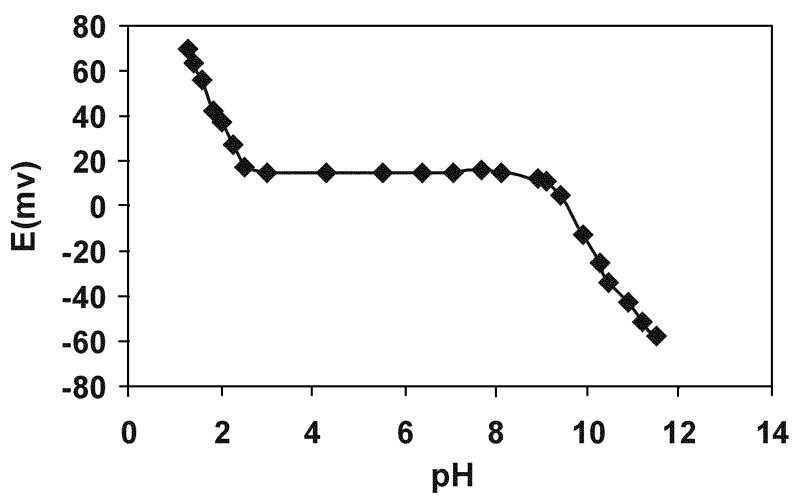

Figure 5. The effect of the $\mathrm{pH}$ of the test solution on the potential response of the lanthanum Sensor. 
Table 2. Selectivity cocfficients for various interfering ions

\begin{tabular}{|c|c|}
\hline Cation & $\mathrm{K}_{\mathrm{AB}}^{\mathrm{UPH}}$ \\
\hline $\mathrm{Pr}^{3-}$ & $7.84 \times 10^{-3}$ \\
\hline $\mathrm{Gd}^{i-}$ & $2.21 \times 10^{-3}$ \\
\hline $\mathrm{Eu}^{i-}$ & $3.12 \times 10^{-3}$ \\
\hline $\mathrm{Ce}^{i-}$ & $9.33 \times 10^{-3}$ \\
\hline $\mathrm{Znj}=-$ & $9.34 \times 10^{-4}$ \\
\hline $\mathrm{Ni}^{2-}$ & $3.64 \times 10^{-1}$ \\
\hline $\mathrm{Cu}^{2+}$ & $3.09 \times 10^{-2}$ \\
\hline $\mathrm{Ca}^{2-}$ & $4.38 \times 10^{-3}$ \\
\hline $\mathrm{Na}^{+}$ & $9.64 \times 10^{-4}$ \\
\hline $\mathrm{Co}^{2+}$ & $1.45 \times 10^{-1}$ \\
\hline $\mathrm{Cs}^{+}$ & $5.91 \times 10^{-3}$ \\
\hline $\mathrm{Li}^{-}$ & $2.38 \times 10^{-4}$ \\
\hline$K^{\prime}$ & $4.60 \times 10^{4}$ \\
\hline $\mathrm{NH}_{4}$ & $2.39 \times 10^{-4}$ \\
\hline
\end{tabular}

primary ion, over other ions present in solution, is perhaps the most important characteristics of an ion-selective electrode. In this work, the potential responses of the proposed $\mathrm{La}(] \mathrm{J})$ membrane sensor to a wide variety of cations, were investigated by the matched potential method (MPM). According to the MPM, ${ }^{22}$ the selectivity coefficient is defined as the activity ratio of the primary ion $\left(\mathrm{A}=10^{-5}\right.$ $10^{-3} \mathrm{M}$ of $\mathrm{L}, \mathrm{ct}(\mathrm{III})$ ion) and the interfering ion $\left(\mathrm{B}=10^{-1}-10^{-3}\right.$ $\mathrm{M})$ that gives the same potential change in a reference solution $\left(1.0 \times 10^{-5} \mathrm{M}\right.$ of $\mathrm{la}$ a(III) ion $)$. Thus, first the change in potential upon changing the primary ion activity is measured, and then the interfering ion would be added to an identical reference solution until the same potential change is obtained.

The selectivity coefficient $\mathrm{K}_{\mathrm{A} B \mathrm{~B}}^{\mathrm{MPM}}$, is determined as:

$\mathrm{K}_{\mathrm{A} . \mathrm{B}}^{\mathrm{MPM}}=\Delta \mathrm{A} / \mathrm{a}_{\mathrm{B}}$, where $\Delta \mathrm{A}=\mathrm{a}_{\mathrm{A}} \Delta \mathrm{a}_{4}, \mathrm{a}_{\mathrm{A}}$ is the initial primary ion activity and $\dot{a}_{+}$the activity of $\mathrm{A}$ in the presence of interfering ion, $\mathrm{a}_{\mathrm{B}}$. The resulting selectivity coefficient values thus obtained for the La(III) membrane electrode, are summarized in Table 2. As it is seen, for all the monovalent cations tested $\left(\mathrm{Li}^{-}, \mathrm{Na}^{-}, \mathrm{K}^{-}, \mathrm{NH}_{4}^{+}, \mathrm{Cs}^{+}\right)$the selectivity coefficients are smaller than $5.91 \times 10^{-3}$. Selectivity coefficients obtained for divalent cations tried $\left(\mathrm{Kn}^{2+}, \mathrm{Ni}^{2}, \mathrm{Ca}^{2-}\right.$. $\left.\mathrm{Co}^{2-}\right)$ are also very small, and in the range $1.45 \times 10^{-4}-4.38 \times$ $10^{-3}$, (except for $\mathrm{Cu}^{2-}$ ). In the case of trivalent cations $\left(\mathrm{Pr}^{3-}\right.$. $\left.\mathrm{Gd}^{3-}, \mathrm{Eu}^{3+}, \mathrm{Ce}^{3+}\right)$ the selectivity coefficients are relatively small (in the range $2.21 \times 10^{-3}-9.33 \times 10^{-3}$ ). The obtained selectivity coefficients indicate that the disturbance produced by these cations in the functioning of the proposed membrane sensor is negligible.
Table 3. Comparison of the sclectivity coefficients of different la(III) electrodes

\begin{tabular}{|c|c|c|c|}
\hline \multirow{2}{*}{ Ions: } & \multicolumn{2}{|c|}{ Selectivity Coefficient } & \multirow{2}{*}{ This work } \\
\hline & Rcf. 21 & R:f 22 & \\
\hline $\mathrm{Co}^{2-}$ & $2.5 \times 10^{-2}$ & $50 \times 10^{-3}$ & $1.45 \times 10^{-4}$ \\
\hline $\mathrm{Cu}^{2-}$ & - & $2.0 \times 10^{-2}$ & $3.09 \times 10^{-2}$ \\
\hline $\mathrm{Ni}^{2-}$ & $2.5 \times 10^{-2}$ & $1.5 \times 10^{-2}$ & $3.64 \times 10^{-4}$ \\
\hline $7 / \mathrm{n}^{2-}$ & - & $2.1 \times 10^{-2}$ & $9.34 \times 10^{-4}$ \\
\hline$S m^{3+}$ & - & $1.5 \times 10^{-2}$ & - \\
\hline $\mathrm{Ce}^{3-}$ & $5.2 \times 10^{-1}$ & $5.0 \times 10^{-2}$ & $9.33 \times 10^{-3}$ \\
\hline $\mathrm{UOO}_{2}{ }^{2+}$ & - & $3.0 \times 10^{-3}$ & - \\
\hline $\mathrm{Ag}^{+}$ & - & $8.1 \times 10^{-4}$ & - \\
\hline $\mathrm{Ph}^{2-}$ & - & $5.0 \times 10^{-2}$ & - \\
\hline $\log g^{2+}$ & - & $5.0 \times 10^{-3}$ & - \\
\hline $\mathrm{Pr}^{3-}$ & - & - & $7.84 \times 10^{-3}$ \\
\hline $\mathrm{Fu}^{3-}$ & - & - & $3.12 \times 10^{-3}$ \\
\hline $\mathrm{Na}^{+}$ & - & - & $9.64 \times 10^{-4}$ \\
\hline $\mathrm{Ca}^{2-}$ & - & - & $4.38 \times 10^{-3}$ \\
\hline $\mathrm{Cs}^{-}$ & - & - & $5.91 \times 10^{-5}$ \\
\hline $\mathrm{L}, \mathrm{j}^{-}$ & - & - & $2.38 \times 10^{-4}$ \\
\hline $\mathrm{Cid}^{3+}$ & - & - & $2.21 \times 10^{-4}$ \\
\hline
\end{tabular}

Table 3 , compares the selectivity coefficients of the La(III) sensor with those of the best previously La(III) electrodes, reported in the literature. ${ }^{20.23}$ From the data given in Table 3 . it is immediately obvious that the selectivity coefficients of the sensor are superior to those reported by other researchers, especially for interfering cations such as $\mathrm{Co}^{2+} \cdot \mathrm{Cu}^{2-}$, $\mathrm{Ni}^{2-}, 7 \mathrm{n}^{2-}, \mathrm{Ce}^{3+}, \mathrm{Pr}^{3+}, \mathrm{Cu}^{3+}, \mathrm{Na}^{+}, \mathrm{Ca}^{2+}, \mathrm{Cs}^{-}, \mathrm{li}^{+}$, and $\mathrm{Gd}^{3-}$.

The $\mathrm{La}(\mathrm{IIJ})$ sensor was successfully used as an indicator electrode in the titration of $25.0 \mathrm{~mL}$ of $1.0 \times 10^{-1} \mathrm{l}$ a(1ll) solution with a $1.0 \times 10^{-2} \mathrm{M}$ E.DTA, and the resulting titration curve is given in Figure 6. As it is seen, the amount

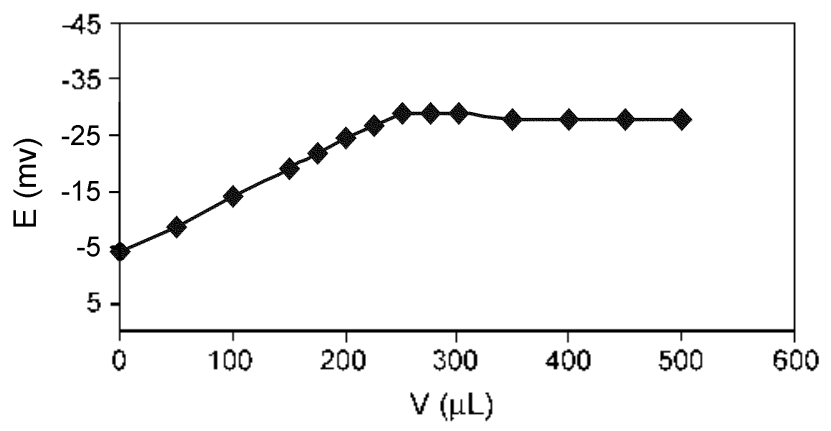

Figure 6. Potentiometric titration curve of $25.0 \mathrm{mI}$. $1.0 \times 10^{-1} \mathrm{M}$ solution of $1 \mathrm{a}^{\mathrm{i}-}$ with $1,0 \times 10^{-2}$ Mol' 1 IJis at $\mathrm{pH} 5,0$.

Table 4. Results of the determination of the lluoride in the three dilierent mouth wash samples

\begin{tabular}{|c|c|c|c|}
\hline Sample & J.abeled & Fluoride electrode & Found ISF." \\
\hline Sodium lluoride mouth wash solution (Chimia I)aru Co.. Tehran, Iran) & $2.0 \%$ & $(1.90 \pm 0.05)^{0 \%}$ & $(2.03 \pm 0.02)^{0} \%$ \\
\hline Sodium Iluoride mouth wash solution (Shahre I)aru (o.. Tehram. Iran) & $0.2 \%$ & $(0.21 \pm 0.01)^{0 \%} \%$ & $(0.24 \pm 0.03)^{0} \%$ \\
\hline Sodium Iluoride tablets (I oghman Pharmaceutical C'o. Tehraln, Iran) & $\begin{array}{c}1.0 \\
\text { mg per tablet }\end{array}$ & $(1.01 \pm 0.03)^{0} \%$ & $\begin{array}{c}(0.98 \pm 0.024) \% \\
\text { mg per tablet }\end{array}$ \\
\hline
\end{tabular}

"Solid state fluoride electrode. "Proposed lanthanum membrane sensor 
of La(III) ion in the solution can be determined with the electrode.

The membrane sensor was used to the determination of fluoride ions in two mouth wash preparation samples. $1.0 \mathrm{~g}$ of each sample was weighed, and diluted with distilled water in a $100 \mathrm{~mL}$ flask and titrated with a $\mathrm{La}^{3-}$ solution ( 1.0 $\left.\times 10^{-\hat{3}} \mathrm{M}\right)$, and the results of three measurements are summarized in Table 4 . As it is seen. there is a satisfactory agreement among the declared fluoride content, the values deternined by the proposed sensor, and conmercial solid fluoride sensor.

Acknowledgements. The authors express their appreciation to the University of Teluran Research Council for financial support of this work.

\section{References}

1. Buhlman, P.: Pretsch, E.: Bakker. E. Chem. Rev 1998, 98. 1539

2. Harrel, I. B: Iones. A. D. Choppin, G. R. Amal. Ghem. 1969, th. 1459 .

3. Szczepaniak. W.: Ren. M. Talanta 1994. H1. 1393

4. Pan. E.: Xuemei. Z.: Huang. Z. Hingrong. Huarie 1994. H. 20.

5. Amarchand. S.: Menon, S. K.: Agarwal, Y. K. Electroanalysis $2000,12,522$

6. Shamsipur M:- Yousefi, M. Ganjali. M. R. Anal Chem. $2000,72$. 2391.

7. Ganjali. M. R.: Qomi. M.: Daftari. A.: Norouzi. P.: Salavati-
Niasari. M.: Rabbani. M. Sens. Actuators B 2004. 98. 92.

8. Ganjali. M. R.: Kiani-Anbouhi. R.: Shamsipur. M.: Poursaberi. T.: Salavati-Niasari. M.: Talebpour. Z.: Emami. M. Electroumalysis 2004. $15,1038$.

9. Ganjali, M. R: Pourjavid, M. R: Rezapour, M.: Haghgoo. S Sens. Actuators $B$ 2003. 89, 21 .

10. Ganjali. M. R.: Tahami. M.: Shamsipur. M:: Poursaberi. I: Haghgoo. S.: Hosseini. M. Electroanatysis 2003. 15. 1038.

11. Ganjali. M. R.: Naji. L.: Poursaberi. T.: Shamsipur. M.: Haghgoo. S. Anal Chim. Acta 2003, 475.59

12. Bush, D. H.: Bailar. J. C. J. Am. Chem. Soc. 1965, 78. 1137.

13. Ganjali, M. R.; Daftari, A.: Mizani. F. Bull. Korean Chem. Soc. 2003. 24. 23.

14. Ganjali. M. R.: Pourjavid. M. R.: Muradzadegan. A.: Hosseini. M.: Mizani. F. Bull. Korean Chem. Soc. 2003. 2t. 1585.

15. Bakker. E. Electroanalysis 1997, 9,7.

16. Ganjali, M. R.: Emami. M.: Salavati-Niasari. M. Bull. Konan Chem. Soc. 2002, 23. 1394.

17. Rosatzin. T.: Bakier. E.: Suzuki. K.: Simon. W. Anal. Chim . Acta 1993. 280. 197.

18. Gehring. P. M.: Morf. W. E.: Welti. N.: Simon. W. Heh: Chent Acta 1990. 73. 203

19. Ganjali, M. R.; Rahimi-Nasrabadi. M.; Maddah. B; Moghimi, A.; Borhany, S. Talanta 2004, 63, 899.

20. Ganjali. M. R.: Daftari. A.: Rezapour. M.: Poursaberi. T.: Haghgoo. S. Tolonta 2003. 59.613.

21. Ammant1. D.: Pretsch. E.: Simon. W.: Lindner. E.: Bezegh. A.: Pungor. E. Anat. Chim Acta 1985. 171. 119.

22. Bailey, P. L. Analysis with Ion-Selective Electrodes: Heyden: London. 1996.

23. Shamsipur. M.: Youseti. M.: Hosseini. M.: Ganjali. M. R. Anol. Chent 2002. 7t. 5538. 